\title{
Health education as an inseparable component of health promotion activities
}

\author{
Weronika Wrona-Wolny @ https://rrid.orgy 0000-0002-029-2912
}

The Department of Health Promotion The Chair of Social Fundamentals of Rehabilitation The Academy of Physical Education of Bronisław Czech, Kraków

Address for correspondence: Weronika Wrona-Wolny, The Department of Health Promotion, The Chair of Social Fundamentals of Rehabilitation, al. Jana Pawła II 78, 31-571 Kraków, weronika.wrona@awf. krakow.pl, tel. $126831397 ; 1260$

\section{Abstract}

The paper presents the role of health education as an inseparable element of health promotion. Both concepts refer to activities that aim to provide support for people to control the factors which may influence their health and to create a healthy environment. The two concepts are different, however, there is a link between health education and health promotion, human health, which is emphasized as being the common focus of these activities. The relationship between health education and health promotion is discussed on the basis of the National Health Programme for 2016-2020 and one of the habitats of a health promoting school. It is also emphasised that taking care of one's health is a lifelong process, which can be perceived in health education and health promoting activities.

In conclusion, it is stated that health education is a necessary tool for health promotion; their combination in various habitats and the areas of social life may induce a synergic effect, contributing to an increase in the effectiveness of the applied health activities.

\section{Key words: health education, health promotion, health, lifelong learning, National Health Proyramme 2016-2020, Health Promoting School \\ Stowa kluczowe: edukacja zdrowotna, promocja zurowia, zdrowie, kstałcenie ustawiczne, Narodowy Proyram Zurowia na lata 2016-2020, Szkoła Promująca Zdrowie}

Przygotowanie do wydania elektronicznego finansowane w ramach umowy 641/P-DUN/2018 ze środków Ministra Nauki i Szkolnictwa Wyższego przeznaczonych na działalność upowszechniającą naukę.

\section{Introduction}

As emphasised by Woynarowska [1], health education is one element of activities undertaken in the field of health promotion. Health education is an action targeted at an individual, whereas health promotion is aimed at the social system. To enable people to participate in promotional activities and make changes in their lifestyles and environment requires them having the appropriate competences, which may be acquired through health education initiatives. Health education is interdisciplinary, hence, it is necessary to consider literature from various areas, such as: pedagogy, psychology, sociology, medicine and others. It should be noted that in the literature the lengthy evolution of the concept of health education can be seen, although the term, incorrectly, is often used interchangeably with the concept of health promotion. As early as 1963, the concept of health education was coined at the Institute of Pedagogy in Warsaw. Health education, in Demel's opinion [2], is "an integral part of shaping a full personality, which involves: the production of habits directly or indirectly related to the protection and improvement of physical and mental health; the creation of appropriate skills; setting the will and shaping attitudes for enabling the application of hygiene principles, effective care, disease prevention and treatment; stimulating positive interest in health issues through episodic and systematic enrichment and deepening the knowledge about oneself and about the rules governing public health."

The purpose of this paper is to present health education as an inseparable component of health promotion and its role in the process. 


\section{Differentiating the concepts of health promotion and health education and their close interrelationship}

The two concepts, health promotion and health education, are closely related. Both health promotion and health education refer to the actions, whose aim is to support people in controlling the factors influencing their health and creating a healthy environment. In the literature on health promotion, there are many attempts to define and understand this concept, which, although diverse, retain a similar content about enhancing and developing health. The most widely known definition of health promotion is that formulated by the WHO and included in the Ottawa Charter, accepted at the First International Conference on Health Promotion (Ottawa 1986). According to this definition, the promotion of health is: "a process that allows each person to increase their influence on their health in terms of improving and maintaining it" [3]. Health promotion according to Lalonde (1974) is a strategy "oriented towards information, influencing and supporting both individuals and organisations, so that they can have a greater sense of responsibility and be more active in matters relating to physical and mental health" [4]. Authors like Allegrante, Barry, Airhihenbuwa and others [5] emphasise the fact that health promotion and health education include many complementary activities that are undertaken by individuals and communities. The literature includes many references to the relationship between health promotion and health education. This close relationship is noticed in the definition of health promotion by Tones and Green [6], which presents a simple equation: health promotion $=$ health education + public health policy. In their opinion, the promotion of health is an activity that includes health education within the broadly understood public health policy. The basic activities of health promotion now include three inseparable elements: health education, disease prevention and the local health policy. Activities undertaken in health promotion initiatives enable individuals and communities to increase control over their health and thereby improve it. The activities attempt to promote a healthy lifestyle, environmental and individual factors conducive to health enhancement. It should be noted that the rational prevention of the most socially aggravating diseases, in connection with social education and the promotion of a healthy lifestyle, may bring the hoped for results. Health promotion is also understood as the creation of conditions that facilitate and encourage a healthy lifestyle. The definition formulated by Green and Kreuter in 1991 [7], known as the American definition, defines the promotion of health as a combination of educational activities and various types of environmental, social, political, economic, legal and tactical support for health. This means that the purpose of education supported from different sides is to facilitate the development of pro-health behaviours, or shaping healthy lifestyles [7]. Kickbusch, a German political scientist, best known for her contribution to health promotion and global health, wrote that health promotion is a process of social change serving the development of people: many entities participate in the process and interdisciplinary knowledge is used in a professional, methodological and creative way [8]. The second concept, health education, is considered to be the basic tool used for health promotion. According to Woynarowska and Sokołowska, it is understood as a process based on scientific principles, to create an opportunity for planned learning and aimed at enabling individuals to make informed decisions about their health and to act in accordance with them. Health education is the process in which people learn to take care of their own health and other people's health. Its main purpose is to influence individual and group health behaviours by enhancing their knowledge or correcting misapprehensions, by shaping attitudes and skills which affect health positively. Education is not only a process of passing on theory, but it occurs when the educated person applies the knowledge in a way that benefits them, which involves thinking, making choices, making decisions and undertaking activities influencing health and lifestyle [9]. The centre of the health promotion model with a focus on empowerment is also occupied by the health education and pro-health public policy, as described below. The task of education aimed directly at the empowerment of individuals and indirectly at societies is to strengthen their capability to act for health and influence public policy makers [1]. Health promotion is a process that will lead to the transformation of individual lifestyles so that it fosters the strengthening and development of the society's health potential. Such transformations are achieved through changes in the awareness and health behaviours of individuals. The relationship between human health and the environment is reflected in the socio-ecological health model, which is the theoretical basis for health promotion. The improvement in the health of society has a significant impact on the socio-economic development of the country [10]. Health education is associated with the desire to improve and protect health by stimulating the learning process, which engenders voluntary changes in the behaviour of individuals. Słońska, after Tannhill, gives three models of health education: a model oriented to disease, to risk factors for health and to health itself [11]. As underlined by Syrek [10], the health-oriented model in health education is extremely useful from the point of view of the effectiveness of achieving a permanent impact on behavioural change and can be treated as the most appropriate for implementing the idea of health promotion. The health-oriented model stems from adopting a holistic approach to health. The main emphasis is on the people and places that should be the subject of the educational activities. The main effort focuses on the development and implementation of comprehensive health education programmes, focused on the social environments that are of key importance to the health of a given community. Educational activities should increase health potential in the physical, mental and social dimensions [12]. According to Woynarowska, health education is a didactic-educational process in which children and adolescents learn the life skills to preserve and improve their own health and other people's health and to create 
a healthy environment. In the case of illness or disability they learn how to actively participate in its treatment or rehabilitation, to cope with it and reduce its negative effects [1]. Health promotion seeks success through its educational impact on individuals and communities and the parallel introduction of pro-health changes in the broadly understood human environment [13]. The basic task of modern health education is the development of health competences for independent and rational pro-health action of individuals and groups in everyday situations and at various levels of the organisation of social life: in the family, in the workplace, in local communities, institutions and organsations led by local and national governments [14]. The basis of these competences is knowledge; the attitude towards health and disease, which is expressed by recognising health as a value, the ability to shape attitudes conducive to health and making the right choices. The hierarchy of values and the sense of responsibility for one's health are closely related to the person's attitudes [15]. For at least 20 years, under the name of "health promotion", intensive activities, primarily in the field of health education, have been conducted in Poland at both the central and local level. Education is not usually accompanied by intersectoral activities directed at controlling the impact of social determinants of health, although there are exceptions [14]. Another definition of health education is proposed by the well-known Canadian theoretician of health promotion L.W. Green, who says that "health education can be defined as a set of planned activities, learning experiences, which are intended to help an individual undertake voluntary healthpromoting activities" [15].

\section{Human health as the basis and goal of health education and health promotion}

Health is a key concept for health education and health promotion. The definitions of health and knowledge about it have developed in two time periods. The first was from ancient times to the 1940s, in which health was defined by the absence of disease, and the second period is comprised of modern and post-modern times [16]. The recognition of a person as being healthy was presented in an interesting way by Talcott Parsons, who as a sociologist "perceived a person in the category of the individual's behaviours", who has to fulfill many social roles in their life. According to this view, a healthy person is one who can perform these roles without problems and disturbances [17]. The 1946 concept of "health" according to the World Health Organization (WHO) is the state of full physical, mental and social well-being, not just the lack of disease or disability [18]. Health promotion refers to environmental, social and institutional factors of the population, while health education concerns the personality factors of the individual. Good health is the result of environmental and personality factors-and provides an incalculable value. The link between health education and health promotion is, therefore, the common objective of the activities, which is enhanced human health. The goal of health promotion is to improve the living conditions of a given population by making it actively participate in the process; the goal of health education is to increase every person's awareness of and give them the knowledge to make pro-health choices, with full social responsibility for the choice. The factor that determines the participation of individuals in pro-health promotional activities is the competences acquired by them from the process of health education.

In addition, the modern concept of health contained in WHO documents emphasises that health: is the value by which an individual or group can, on the one hand, realise their aspirations and satisfy needs and, on the other hand, actively change and cope with the environment; it is the resource which guarantees the social and economic development of society; it is the means, and not the goal, for achieving a better quality of life [19]. The essence of the new approach to health is to make people aware that they need to make decisions and choices about their health. This new approach arose from the recognition in the second half of the $20^{\text {th }}$ century that good medical care does not guarantee good health society and the search for non-medical conditions for good health began. The concept of the health field proposed by Lalond proved to be a breakthrough in this respect [20]. It revealed that in developed countries four groups of factors determining human health can be distinguished: lifestyle and health behaviours, which currently are the greatest determinants (50-60\%); the physical and social environment in which people live (20-25\%); genetic factors (about 20\%) and corrective medicine, health care, can now solve only $10-15 \%$ of health problems [1]. Health is a resource for education as it predisposes systematic learning, influences the development of talents and interests and mastery of various skills. In addition, factors that affect education and health can be described as similar. In relation to children and young people, the socio-economic factors of the family, the local environment, family members and peers have a significant impact [20]. Human health began to be considered holistically. The holistic model of health drew attention to the various facets of health such as physical associated with the proper biological functioning of the body as a whole; psychological-related to cognitive and emotional functioning; social - also relating to cognitive and emotional functioning and spiritual - associated with personal convictions and beliefs or religious practices [1]. Health is also an inherent condition for school achievement, by equipping children and teenagers with the knowledge, skills and appropriate attitudes towards health, by which their chances for a healthy life and their ability to act for the community's health can be increased.

\section{A model of health promotion focused on empowerment}

According to Woynarowska [1], the contemporary model of health promotion is directed towards the empowerment of individuals and communities. Empowerment is a concept that addresses various aspects of people's control over their lives and taking responsibility for their health-related decisions. The final outcome of 
health education should be individuals, communities and professional groups who are empowered and ready to act competently to ensure their health. According to Woynarowska and Woynarowska-Sołdan [21], in health promotion, empowerment means that individuals or communities gain the possibility, through their own actions and strength/ power, to control their own health and environment, manage their lives and take responsibility for their decisions related to health. The focus is on the activity of individuals and communities, willingness, giving freedom for the choices, decisions and actions at the individual and community level. Therefore, there are two forms of empowerment, which are mutually interrelated: a) the empowerment of individuals, which refers to the individual's ability to make decisions and control their own life and health; b) the empowerment of communities, which means that individuals act together to have greater influence and control of the factors that condition the health and life quality of the community [21]. Woynarowska [1] has also divided the concept into psychological and social empowerment. The psychological aspect refers to the subjective sense of control over one's own life and health, which is experienced in the physical and social environment. The social empowerment involves the process of social activities, requiring the participation of people, organisations and communities to increase their individual and joint control over the conditions and quality of life, including health-related activities. In the model of health promotion geared towards empowerment, the complexity of actions taken and the large number of entities that should participate in them can be detected. According to McLeroy, it should be recognised that experts making interventions in the field of health education, should not replace the individuals and groups involved, but should improve their competences and increase their ability to act independently [22]. According to the theory of health promotion and its functions, as discussed earlier, the general change of anti-health to pro-health behaviours requires not only an educational impact on individuals and communities at all stages of human life, but also achieving pro-health changes in the broadly understood social, cultural, material and economic environment [22].

\section{Health education in the process of lifelong learning}

The lifelong learning of society in the field of health education is understood to be a continuous and perpetual process of constantly gaining and deepening knowledge and improving the society's health-related skills. It is also very important to shape a mature attitude towards health so that continuous self-improvement results from the natural need to care for it. Lifelong learning is the process of constantly renewing, improving and developing general and professional qualifications of an individual throughout their life. This education can take place by participating in various training courses, professional and hobby courses, postgraduate studies, study trips, conferences, seminars, as well as by watching or listening to educational programmes, reading magazines, learning via the Internet, distance learning [23].

Lifelong learning may be taken on the initiative of a person who cares about health in order to raise and improve their knowledge, skills and to shape their attitude towards health. It is not possible, therefore, to take care of one's own health only on the basis of the knowledge gained at school, as one's knowledge must be constantly renewed, enhanced and developed throughout life. Continuous health education is a systematic lifelong learning process that in a modern society, the era of globalization, economic development with the IT and telecommunications revolution, has become a particularly important aspect of life. The concept of continuous learning is understood in many ways, sometimes used interchangeably with terms such as lifelong learning and permanent education. Aleksander [24] interprets the concept as follows: ,lifelong learning is simultaneously an idea, a process and a principle. It requires lifelong implementation in a continuous way, without interruption. According to Woynarowska [1] "health education is a lifelong process of learning by people on how to live: to preserve and improve one's own and others' health; to actively participate, to cope with and reduce any negative effects in the case of disease or disability." Charońska [25] emphasises the continuous nature of health education, defining it as a "a lifelong process, containing all activities aimed at shaping, acquiring and developing the competences needed to lead a healthy lifestyle, and effectively influence one's own health and that of the community in which one lives." The lifelong nature of health education is reflected in the shaping of life skills, acquiring health resources through one's-whole life in the salutogenic model of Antonovsky [26] and in the promotion of mental health in different periods of human life and environments. Caring for health should not finish at the end of school education, but it should last throughout one's whole life. The interdisciplinary character and complexity of health education in the process of continuous education should be the inspiration for various activities in the field of health care.

In the promotion of mental health a lifelong process is seen. To ensure positive mental health, in line with the Lisbon Strategy guidelines, the promotion of mental health in each country should implement the following ten areas of activity: supporting parenthood and the first years of life; promoting mental health in schools; promoting mental health at work; supporting mental health while ageing; dealing with groups at risk of mental disorders; preventing depression and suicide; preventing violence and the harmful use of psychoactive substances; involving primary and secondary health care; reducing social impairment and preventing stigma and establishing cooperation with other sectors [27]. Positive mental health cannot be obtained only by treating mental disorders, but it is a matter of concern for every human being and a problem faced by various sectors, including education, which also indicates the need for continuous education in this field. 
Health education is the best investment for ensuring human health, it should continue throughout life, in the various habitats in which a person resides, such as a home, school or workplace.

Health education in the process of continuous education in contemporary society is related to obtaining the resources for health throughout life in the salutogenic model of Antonovsky and to promoting mental health in various environments and periods of human life.

\section{Activities in the field of health promotion and health education in the National Health Programme for 2016-2020}

The combination of health promotion and health education is seen in previous editions of the National Health Programme, as well as in the current programme for 2016-2020. The role of health promotion in shaping the country's health policy was presented in the 1990 National Health Programme. It was the first attempt to make various government administration bodies, nongovernmental organizations and local communities take action to protect, maintain and improve the health of Polish society. Health promotion, which was introduced in the 1970s, is the main strategy of the World Health Organization (WHO) and is the basic assumption of the Polish National Health Programme. The National Health Programme (in Polish: NPZ) is a strategic document focusing on public health in Poland. The strategic objective of the NPZ for 2016-2020, accepted by the Council of Ministers of 4 August 2016, assumes "extending healthy life, improving health and related health quality and reducing social inequalities in health". The strategic objective of the National Health Programme is implemented through six operational goals [28]. The implementation of the strategic objective as well as the operational goals requires the inclusion of activities in the field of health promotion and health education. Under the first operational goal referring to the improvement of diet, nutritional status and physical activity of society, health education activities are undertaken to improve public awareness of the importance of a properly balanced diet and the benefits of regular physical activity for the prevention of non-communicable chronic diseases. Health education should also help to change bad eating habits into good eating habits and encourage physical activity. As part of these activities in the field of health education, information and educational activities have been planned to promote a healthy lifestyle in various social groups. The implementation of the second operational goal relating to prevention and solving problems connected to the use of psychoactive substances, behavioural addictions and other risky behaviours also requires information and educational activities. These are intended to shape health awareness and motivation to care for the health of school children and teenagers, with particular emphasis on the risks of using psychoactive substances and their negative consequences. To implement the third operational goal for the prevention of mental health problems and improvement of the mental well-being of society, it is necessary to carry out information and educational activities. These should disseminate knowledge about mental health and its conditions, shape beliefs, attitudes, behaviours and lifestyles supporting mental health and developing skills to deal with situations threatening mental health. The fourth operational goal to reduce the risk to health resulting from physical, chemical and biological hazards in the external environment, place of work, residence, recreation and science also requires health promotion activities. These activities should shape healthy environments and incorporate educational programmes, including dissemination of knowledge about the harmful effects of chemical substances on human health and the environment and minimising the impact on human health of chemical agents used in the home and the workplace. The fifth goal related to the promotion of healthy and active ageing, comprised in the 2016-2020 NPZ, involves pursuing a seniors' policy aimed at the long-term social, professional and family activities of older people, including creating a senior-friendly public space, taking into account the needs of disabled people. Educational activities are to contribute to the popularisation of knowledge about the specific needs of the elderly population. It is also necessary to educate health care workers in the field of geriatric and gerontological issues as well as providing comprehensive care for the elderly and early detection of diseases characteristic of old age. For the implementation of the sixth and last goal to contribute to the improvement of reproductive health, a number of important activities in the field of health promotion and health education were planned in the interests of procreative health, which conditions the state of health of Poles, good health of the next generations and improvement of demographic indicators [28].

To implement the specific operational goals included in the National Health Programme for 2016-2020, comprehensive and multi-sectoral activities in the field of health education and health promotion to ensure the health of the Polish population are necessary.

\section{The Health Promoting School - as an example of a habitat that implements activities in the field of health education and health promotion}

Health education is an inseparable element of health promotion, including that by the Health Promoting School (HPS). In order for people to want to take action for their health, they should be equipped with the appropriate competences [29]. A health promoting school creates favourable conditions for the implementation of health education for pupils and employees: by creating policies, conditions and the organisation of school life in a manner conducive to the effectiveness of health education; encouraging students to actively participate in the planning, implementation and evaluation of health education; collaborating with parents and the local community in the implementation of health education; conducting evaluation of the results of health education and the use of these results to improve its quality [30]. The Health Promot- 
ing School programme, as emphasised by Woynarowska [1], is the most widespread and dynamically developing project in the area of health promotion. The basis of the programme is the concept of health promotion and the outcome arising from several international scientific conferences devoted to school health education [31]. Woynarowska [31] defines a health promoting school in Poland as a school which "in cooperation with the pupils' parents and the local community systematically creates a social and physical environment conducive to health and well-being of the school community, supports the development of pupils' and employees' competences to ensure lifelong care for health." The basis for the concept of HPS is the assumptions of health promotion, according to which: "health is created by people in everyday life, in all habitats where they live, learn, work, relax and play; one of the habitats is the school and its community - teachers, non-teaching staff, pupils and their parents. Two interrelated actions are needed: individual actions by people who strive to have a healthy lifestyle and community activities that create a healthy physical and social environment. The condition for the effectiveness of these activities is participation, the involvement of as many members of the given community as possible. Health promotion programmes are implemented «with people» and not «for people» and at school the participation of teachers, other employees, pupils (real and not apparent) and cooperation with the pupils' parents is necessary" [23]. The health promoting school is characterised by three basic features [30], which define its course of action: health education as an inseparable element of the teaching curriculum; health issues permeating throughout the school's activities, which can be defined as a hidden school programme, or ethos, involving school relations and atmosphere, patterns created by teachers, the physical environment and many other characteristics of school life; the school's cooperation with parents and the entire community in which the school exists. Bulska [32] emphasises that the health promoting school through a wellthought-out strategy of cooperation and partnership in the field of health education is the best example of the efficient promotion of health activities and obtaining support from the local community. It provides values that are important from the health, social and cultural point of view. Woynarowska and Sokołowska [33] specify the following elements within the activities undertaken by health promoting schools: (a) the habitat approach - the school is treated as a habitat, a place of living, learning and working for members of the school community, which is connected to other habitats in the local community; (b) a participatory approach involving all members of the school community; (c) an approach from people to the problem; (d) the introduction of systemic changes; (e) the democratisation of school life; (f) building an atmosphere of dialogue and cooperation at school. Grossmann and Scala [34] define health promotion as "the art of intervening in social systems and encouraging them to develop towards healthy environments." These authors emphasise that there is no separate system for health in society and that it should be in the organisa- tion of every social system. Therefore, an important issue in health promotion is the habitat approach - the places where people live, study or work [34]. It is worth quoting a definition of health promotion as: "social and political action at the individual and collective level, the aim of which is to raise the health awareness of society, to promote a healthy lifestyle and create healthy conditions. It is a process to activate local communities, politicians, professionals and laymen, which is undertaken to achieve lasting behavioural changes which reduce the risk to health, to disseminate pro-health behaviour and to introduce changes in the environment that would reduce or eliminate social and other environmental threats to health" [35].

Considering the outlined multifaceted tasks and the very broad psychological and social context, health promoting schools are an example of the habitats that have developed a model of activities based on the strategies employed in the field of health promotion and health education. Health promoting schools through well-established cooperation and partnership in the field of health education and health promotion activities are the best example of the efficient promotion of health activities and for obtaining support from the local community. The values conveyed by them are important, not only from the health point of view, but also from the social and cultural point of view.

\section{Summary}

It is concluded that health education is a necessary and inseparable key component of health promotion, and their combination in various habitats and areas of social life may have a synergic effect, contributing to an increase in the effectiveness of health actions. Success in the process of promoting health requires the active involvement of a population with the appropriate knowledge and skills. Health education, understood in this way, seeks to improve and protect health by stimulating the learning process, leading to changes in the behaviour of individuals. The activities encompassed in the field of health education include raising the level of people's health knowledge, informing them about health threats, building their high self-esteem, their independence and shaping their responsibility for their own health. Health education is treated not as a way to obtain a change in individual behaviours, which are known to be risk factors, but as a means of mobilising all available social forces for the very broadly understood changes that benefit health, including changes in environmental conditions. Health education is the cheapest proven effective action to improve health and is an important tool for health promotion.

\section{References}

1. Woynarowska B., Edukacja zdrowotna. Podręcznik akademicki, Wydawnictwo Naukowe PWN, Warszawa 2007: 137-139.

2. Demel M., Pedagogika zdrowia, WS i P, Warszawa 1980. 
3. Tang Kwok-Cho, Beaglehole R., O’Byrne D., Policy and partnership for health promotion addressing the determinants of health, "Editorials. Bulletin of the World Health Organization" 2005; 83 (12): 884.

4. Wysocki M.J., Miller M., Nowe zdrowie publiczne, in: Nosko J. (ed.), Zdrowie publiczne w zmieniajacej się Europie $i$ w Polsce, Instytut Medycyny Pracy im. Prof. J. Nofera, Łódź 2004: 146.

5. Allegrante J.P., Barry M.M., Airhihenbuwa C.O., Auld E., Lamarre M.C.,Taub A., Towards international collaboration on credentialing in health promotion and health education: The Galway Consensus Conference, "Health Education \& Behavior" 2009; 36 (3): 427-436.

6. Naidoo J., Wills J., Health Promotion. Foundations for Practice. Bailliere Tindall, London 1994: 98-99.

7. Bik B., Przewoźniak L., Henzel-Korzeniowska A., Szczerbińska K., Wybrane zagadnienia promocji zdrowia, Szkoła Zdrowia Publicznego, Centrum Medyczne Uniwersytetu Jagiellońskiego, Kraków 1996: 15-16.

8. Kickbusch I., Think health: What makes the difference, "Health Promotion International" 1997; 4: 265-272.

9. Woynarowska B., Sokołowska M., Jak tworzymy szkotę promujaca zdrowie, Hera, Warszawa 1994: 10.

10. Syrek E., Zdrowie w aspekcie pedagogiki społecznej, Wydawnictwo Uniwersytetu Śląskiego, Katowice 2000: 10.

11. Słońska Z., Ewolucja modeli edukacji zdrowotnej, "Kultura Fizyczna" 1994; 5-6: 16-20.

12. Słońska Z., Instytucjonalne determinanty wspótpracy instytucji zdrowia publicznego i telewizji publicznej w zakresie edukacji zdrowotnej, "Zeszyty Naukowe Ochrony Zdrowia. Zdrowie Publiczne i Zarządzanie” 2018; 16 (1): 12-19.

13. Charońska E., Janus B., Promocja zdrowia i edukacja zdrowotna, "Pielęgniarstwo" 2009; 3 (44): 22-26.

14. Słońska Z., Koziarek J., Społeczne nierówności w zdrowiuefekt medykalizacji promocji zdrowia, "Zeszyty Naukowe Ochrony Zdrowia. Zdrowie Publiczne i Zarządzanie" 2011; IX(2): 64-75.

15. Indulski J., Jethon Z., Dawydzik L.T., Zdrowie publiczne, Instytut Medycyny Pracy, Łódź 2000: 321-323.

16. Malinowski A., Waleologia - nauka o promocji zdrowia, in: Jopkiewicz A. (ed.), Auksologia a promocja zdrowia, Vol. 2, Polska Akademia Nauk, Kraków, Kieleckie Towarzystwo Naukowe, Kielce 2000: 317.

17. Szewczyk T., Edukacyjne i ekologiczne konteksty promocji zdrowia, in: Głowacka M.D. (ed.), Promocja zdrowia. Konteksty spoleczno-kulturowe, Wolumin, Poznań 2000: 180.

18. Nosko J., Zachowania zdrowotne i zdrowie publiczne aspekty historyczno-kulturowe, Instytut Medycyny Pracy, Łódź 2005: 234.

19. Bik B., Koncepcja promocji zdrowia, in: Czupryna A., Paździoch S., Ryś A., Włodarczyk W.C. (eds.), Zdrowie publiczne, part II, Vesalius, Kraków 2001: 214.

20. Woynarowska B., Edukacja zdrowotna - zagadnienia ogólne, in: Woynarowska B. (ed.), Organizacja i realizacja edukacji zdrowotnej $w$ szkole. Poradnik dla dyrektorów szkót i nauczycieli gimnazjum, Ośrodek Rozwoju Edukacji, Warszawa 2014: 9-10.
21. Woynarowska B., Woynarowska-Sołdan M., Koncepcja i zasady tworzenia oraz rozwoju szkół promujacych zdrowie w Polsce, in: Woynarowska B. (ed.), Szkoła promujaca zdrowie. Poradnik dla szkót i osób wspierających ich działania w zakresie promocji zdrowia, Ośrodek Rozwoju Edukacji, Warszawa 2016: 11, 102.

22. McLeroy K., Book review of health promotion at the community level, "Health Education Quarterly" 1993, 20 (1): 133-136.

23. https://pl.wikipedia.org/wiki/Kształcenie_ustawiczne (accessed: 1.12.2018).

24. Aleksander T., Kształcenie ustawiczne, in: Pilch T., Lepalczyk I. (eds.), Pedagogika społeczna, Żak, Warszawa 1995: 295.

25. Charońska E., Podstawy teoretyczne edukacji zdrowotnej, in: Andruszkiewicz A., Banaszkiewicz M. (eds.), Promocja zdrowia dla studentów studiów licencjackich kierunku pielęgniarstwo i położnictwo, Vol. I, Teoretyczne podstawy promocji zdrowia, Czelej, Lublin 2008: 130.

26. Antonovsky A., Rozwikłanie tajemnicy zdrowia, transl. H.J. Grzegołowska-Klarkowska, Wydawnictwo IPN, Warszawa 1995.

27. Jane-Llopis E., Anderson P., Mental Health Promotion and Mental Disorder Prevention. A Policy for Europe, Nijmegen: Radboud, University Nijmegen, Nijmegen 2005: 7.

28. http://www.mz.gov.pl/zdrowie-i-profilaktyka/narodowy-program-zdrowia/npz-2016-2020/cele-operacyjne-npz/ (accessed: 29.11.2018).

29. Woynarowska B., Szkoła promujaca zdrowie, in: Woynarowska B. (ed.), Edukacja zdrowotna. Poradnik dla nauczycieli wychowania fizycznego w gimnazjach i szkołach ponadgimnazjalnych, Wydawnictwo Pedagogiczne ZNP, Kielce 2012: 228-233.

30. Sokołowska M., Lutze I., Standard szósty. Szkoła promujaca zdrowie prowadzi edukację zdrowotna uczniów i pracowników oraz dąży do zwiększenia jej jakości i skuteczności, "Edukacja Zdrowotna i Promocja Zdrowia w Szkole" 2006; 11: 83-91.

31. Woynarowska B., Edukacja zdrowotna w różnych siedliskach. Szkoła promujaca zdrowie. in: Woynarowska B., Edukacja zdrowotna. Podstawy teoretyczne. Metodyka. Praktyka, PWN, Warszawa 2017: 219-227.

32. Bulska J., Edukacja zdrowotna i promocja zdrowia w Szkole Promujacej Zdrowie - działalność na rzecz wspótpracy ze środowiskiem lokalnym, "Humanum. Międzynarodowe Studia Społeczno-Humanistyczne" 2017; 25 (2): 155-162.

33. Woynarowska B., Sokołowska M., Koncepcja, strategia, organizacja i model tworzenia szkoły promujacej zdrowie, in: Woynarowska B., Sokołowska M. (eds.), Szkoła promująca zdrowie. Doświadczenia dziesięciu lat, Krajowy Ośrodek Wspierania Edukacji Zawodowej, Warszawa 2000: 23-36.

34. Nosko J., Zachowania zdrowotne i zdrowie publiczne aspekty historyczno-kulturowe, Instytut Medycyny Pracy, Łódź 2005: 241.

35. Karczewski J., Higiena. Podręcznik dla studentów pielęgniarstwa, Czelej, Lublin 2002: 23. 